\title{
A reverse phase HPLC method for the quantification of HIV gp145 glycoprotein levels in cell culture supernatants
}

\author{
José González-Feliciano ${ }^{1}$, Coral Capó-Vélez ${ }^{1}$, Pearl Akamine ${ }^{1}$, Manuel Delgado-Vélez ${ }^{1}$, \\ Ruth Almodóvar ${ }^{2}$, Javier Rivera ${ }^{2}$, Ignacio Pino ${ }^{2}$, Gloriner Morell ${ }^{2}$, Daniel Eichinger ${ }^{2}$, José \\ Rivera $^{2}$, José Lasalde-Dominicci ${ }^{3}$, and Abel Baerga-Ortiz ${ }^{4}$ \\ ${ }^{1}$ University of Puerto Rico Molecular Sciences Research Center \\ ${ }^{2}$ CDI Laboratories \\ ${ }^{3}$ University of Puerto Rico Rio Piedras \\ ${ }^{4}$ University of Puerto Rico Medical Sciences Campus
}

July 16, 2020

\begin{abstract}
A reverse phase high performance liquid chromatography (RP-HPLC) method was developed for the quantitative determination of recombinant HIV-1 gp145 produced in CHO-K1 cells, as measured directly in culture supernatants. Samples were diluted in $50 \%$ D-PBS and 50\% PowerCHO-2 (PC2) spent media, and resolved on a Zorbax 300SB-C8 Rapid Resolution (2.1 x 50 mm, 3.5 $\mu \mathrm{m}$ ) column, fitted with a C8 guard column (Zorbax 300SB-C8, $2.1 \times 12.5 \mathrm{~mm}, 5 \mu \mathrm{m}$ ), using 0.1\% TFA and 2\% n-propanol as mobile phase A and $0.1 \%$ TFA, $70 \%$ isopropanol, and $20 \%$ acetonitrile as mobile phase $\mathrm{B}$. The column temperature was $80^{\circ} \mathrm{C}$, the flow rate $1 \mathrm{ml} / \mathrm{min}$ and the absorbance monitored at $280 \mathrm{~nm}$. The procedures and capabilities of the method were evaluated against the present criteria for linearity, limit of detection (LOD), accuracy, precision, and robustness of the International Conference on Harmonization (ICH) guidelines. Two different variants of the HIV-1 envelope protein (Env), CO6980v0c22 gp145 and SF162 gp140, were analyzed and their retention times were found to be different. The methods showed good linearity $(\mathrm{R} 2=0.9996)$, a lower LOD of $2.4 \mu \mathrm{g} / \mathrm{ml}$, and an average recovery of $101 \%$. The analysis includes measurements of accuracy, inter-user precision, and robustness. Overall, we present a RP-HPLC method that could be applied for the quantitation of cell culture titers for this and other variants of HIV Env following ICH guidelines.
\end{abstract}

\section{Introduction}

The envelope (Env) glycoprotein that spans the membrane envelope of the human immunodeficiency virus (HIV) and mediates viral infection has been a common template for the design of numerous vaccine candidates (Aldon et al., 2018; Berman et al., 1990; Guenaga et al., 2016; Ho et al., 1987; Kovacs et al., 2012; Pantophlet \& Burton, 2006; Sanders \& Moore, 2017; Wieczorek et al., 2015; Wintsch et al., 1991). In HIV-infected cells, Env is naturally made as a membrane-spanning gp160 glycoprotein that is cleaved into two glycoprotein fragments: a trimeric gp41 and its monomeric binding partner gp120. The monomeric gp120 was used as the boost immunogen in the RV144 clinical trial in Thailand; the only vaccine trial that has so far resulted in significant HIV protection with an efficacy level of 31.2\% (Rerks-Ngarm et al., 2009). The gp120 monomer is still under evaluation in clinical trials in Thailand and South Africa (Easterhoff et al., 2017; Gray et al., 2014; Harper, 2017). Although some of the early results obtained with the gp120 monomer as a boost immunogen were promising, the development of a globally protective immunogen will require proteins that elicit a more durable and targeted response.

The search for Env-based vaccines of higher efficacy and breadth has led some researchers to look beyond monomeric gp120. More recent immunogen designs have aimed to preserve the trimeric structure of the 
native Env spike, by including portions of trimer-forming gp41 covalently linked to the otherwise monomeric gp120 (Guenaga et al., 2016; Kovacs et al., 2012; Sanders et al., 2002; Wieczorek et al., 2015). In this new category of trimeric Env immunogens there are uncleaved trimers (due to a mutated cleavage site), native trimers (gp120:gp41 complexes held together by an engineered disulfide bond), and several genetically fused constructs (gp120:gp41 held together by a flexible peptide linker). Many of these new trimeric Env constructs, like their monomeric predecessors, are made in mammalian cell expression systems such as CHO and HEK-293, both of which are known to decorate the protein with a native-like glycosylation pattern (González-Feliciano et al., 2020; Bale et al., 2018; Chung et al., 2014; Dey et al., 2018; O'Rourke et al., 2018; Weiss \& White, 1993). However, the typical yields of Env-based proteins made in these tried and tested cellular hosts is about 10-100 times lower than the yields for other glycoproteins of pharmaceutical relevance, posing both a challenge and an opportunity for the optimization of upstream processes (O'Rourke et al., 2018).

To facilitate the optimization of cultivation parameters during upstream and downstream process development, it is important to monitor Env production directly in the supernatants of cultured cells. To date, the most widely used quantitation method for secreted soluble Env immunogens in the culture media is the ELISA method (Bale et al., 2018; Chung et al., 2014; Dey et al., 2018; Fenouillet et al., 1997). Although ELISA is sensitive and inexpensive, comparative studies have shown that the reproducibility of the ELISA method is low, probably due to the variability of the required antibodies (S. B. Hansen et al., 2005).

In this work, we describe the development of a reverse phase HPLC assay for the quantitative detection of the CO6980v0c22 gp145 trimer directly from a culture of CHO-K1 cells that were stably transfected to express the immunogen (Wieczorek et al., 2015). We present the results obtained as part of the development, optimization, and qualification of the RP-HPLC analytical method, as well as its implementation in a manufacturing process.

\section{Experimental}

Materials, reagents and chemicals

The Galanthus nivalis lectin (GNL)- and Q-sepharose-purified HIV-1 CO6980v0c22 gp145 reference material (RM) expressed in CHO-K1 cells was obtained from Advanced Bioscience Laboratories (ABL Inc.). HIV-1 SF162 gp140 recombinant protein produced in HEK 293T cells (Cheng-Meyer et al ., 1989; Stamatatos et al ., 1998 Stamatatos et al ., 2000; Sellhorn et al ., 2009) was provided by the NIH AIDS Reagent Program, Division of AIDS, NIAID, NIH. Acetonitrile, isopropanol, methanol, $n$-propanol, trifluoroacetic acid (TFA), and LC-MS grade water, were purchased from Honeywell. The Dulbecco's Phosphate-Buffered Saline (DPBS, Corning) 1X without calcium and magnesium was obtained from VWR. CHO-K1 PC-2 spent medium was obtained from CDI Laboratories.

\section{Preparation of standards and mobile phase}

The CO6980v0c22 gp145 reference material (RM) diluted in D-PBS 1X was used to prepare the standards for method development. Different concentrations of CO6980v0c22 gp145 RM (12.5, 25, 37.5, 50, 75, and 100 $\mu \mathrm{g} / \mathrm{ml}$ ) were diluted in 50\% CHO-K1 spent medium (final concentration 50\% D-PBS 1X and 50\% CHO-K1 spent medium). The buffer blank was prepared by mixing D-PBS $1 \mathrm{X}$ and CHO-K1 spent medium at 1:1 ratio. Mobile phase A consisted of $0.1 \%$ TFA and $2 \% n$-propanol in LC-MS water and mobile phase B consisted of $0.1 \%$ TFA, $70 \%$ isopropanol, and $20 \%$ acetonitrile in LC-MS water.

\section{Chromatographic conditions}

Chromatographic separation was performed on an Agilent Technologies 1260 Infinity BioInert HPLC quaternary pump system equipped with a diode array detector (DAD VL+). A reverse-phase C8 column (Zorbax 300SB-C8 Rapid Resolution $2.1 \times 50 \mathrm{~mm}, 3.5 \mu \mathrm{m}$ ) and C8 guard column (Zorbax 300SB-C8, $2.1 \times 12.5$ $\mathrm{mm}, 5 \mu \mathrm{m}$ ) were used. The following gradient elution was used (time/\%B): $0 / 30,2 / 30,3.5 / 65,4 / 70,5 / 75$, $6.5 / 95,9.5 / 95$, and $10 / 30$, with a post time of 5 minutes. The following HPLC running conditions were used: injection volume was $40 \mu \mathrm{l}$, flow rate was maintained at $0.4 \mathrm{ml} / \mathrm{min}$, detection was performed at 280 
$\mathrm{nm}$ and column temperature was $800 \mathrm{C}$. To reduce the carry over, $100 \mu \mathrm{l}$ of D-PBS $1 \mathrm{X}$ was injected between sample or standard injections.

Evaluation of the RP-HPLC method against ICH guidelines

The RP-HPLC method for the quantitation of CO6980v0c22 gp145 was evaluated against the current criteria for linearity, LOD, accuracy, precision, and robustness of the ICH guidelines Q2 (R1) (ICH Guidelines, 1996)

Cell culture and western blotting

Stably transfected CHO-K1 cells expressing CO6980v0c22 gp145 were grown in PowerCHO 2 (Lonza) medium supplemented with $10 \mu \mathrm{g} / \mathrm{ml}$ puromycin, $4 \mathrm{mM}$ glutaMAX and $1 \%$ penicillin/streptomycin. A seeding density of 0.8 million cells/ml was used to inoculate a 40L vessel controlled by a Finesse G3Lite (ThermoFisher Scientific) system with an agitation of $65 \mathrm{rpm}$, dissolved oxygen $35 \%, \mathrm{pH} 6.8$ with $\mathrm{CO}_{2}$ adjustment, and a reactor temperature of $37^{\circ} \mathrm{C}$. After each harvest day, a culture sample was removed from the bioreactor for CO6980v0c22 gp145 titer analysis. The sample was mixed 1:1 with gel sample buffer and analyzed by SDS-PAGE using 4-20\% acrylamide (Invitrogen). The bands on the gel were transferred onto a nitrocellulose membrane, that was subsequently incubated with the broadly neutralizing antibody 4 E10 (Polymun Scientific Immunbiologische Forschung GmbH). The secondary labeling step was performed using anti-human IgG coupled with alkaline phosphatase (ThermoFisher) and the resulting bands were visualized on a Chemidoc XRS+ (BioRad). The quantitative analysis of western blot bands was carried out by densitometry using Image Lab Software from Bio Rad.

\section{Results}

\section{Method Specificity}

To evaluate the specificity of our analytical method, the CO6980v0c22 HIV-1 gp145 (clade C) and SF162 gp140 (clade B) were analyzed by RP-HPLC. Since the intended use for this method is the quantitation of CO6980v0c22 gp145 directly from the bioreactors, both CO6980v0c22 gp145 and gp140 standards of known concentrations were mixed 1:1 with PC2 spent medium to a final concentration of $60 \mu \mathrm{g} / \mathrm{ml}$. Three consecutive injections of $40 \mu \mathrm{l}$ were analyzed by RP-HPLC. As shown in Figure 1 and Table 1, our RP-HPLC method can discriminate between these two very similar HIV-1 Env immunogens: CO6980v0c22 gp145 and SF162 gp140. Retention times of 5.385 min and 5.489 min were observed for CO6980v0c22 gp145 and SF162 gp140, respectively (Table 1). In addition, our results revealed that the sample matrix does not interfere with the measurements, since no peaks were observed between 5-6 minutes following the blank injections. Peaks arising from other media components are only observed between 0-2 minutes (Figure 1).

\section{Linearity and Range}

A series of CO6980v0c22 HIV-1 gp145 standard samples, ranging in concentration from 12.5 to $100 \mu \mathrm{g} / \mathrm{ml}$, and each containing 50\% D-PBS 1X and 50\% PC2 spent medium, were injected sequentially into the HPLC system. The area under the peak (AUP) was obtained for each sample and the mean and relative standard deviation (RSD) were calculated for each run. In addition, the slope, Y-intercept, and correlation coefficient were determined from the linear regression analysis. Results in Table 2 and Figure 2 show the linear correlation between AUP and the concentration of CO6980v0c22 gp145 in the sample. The correlation coefficient for the calibration curve shown in Figure 2 was 0.9996 and the average for three independent experiments carried out on different days, is 0.997 with a standard deviation of 0.0002 . Additional parameters of the regression equation are shown in Table 2.

\section{Accuracy}

The CO6980v0c22 gp145 concentrations of $12.5,25,37,5,50,75$ and $100 \mu \mathrm{g} / \mathrm{ml}$ were used to determine the accuracy of the RP-HPLC method. The percent recovery was $100.56 \pm 2.44$ with a percent RSD below $2.7 \%$ (Table 3). Collectively, these results indicate that the RP-HPLC method described herein is suitable for the quantitation of CO6980v0c22 gp145 directly from bioreactor supernatants. 


\section{Precision}

The repeatability (inter-day variation) was determined from the results from six independent injections of a sample containing $60 \mu \mathrm{g} / \mathrm{ml}$ of CO6980v0c22 gp145 RM (Table 4). The concentration of $60 \mu \mathrm{g} / \mathrm{ml}$ was chosen because it lies in the middle of the linear range. Results show a \%RSD of 0.34 for the inter-day variation. Moreover, for the intermediate precision, the differences between different users were recorded and evaluated (Table 4). The experiments were carried out on different days and with fresh solvent each day. The overall \%RSD for the intermediate precision is 1.53 .

\section{Robustness}

The robustness was assessed by using the following variables: column ageing, column guard lot variations, and sample stability. For the column ageing, the RP-HPLC method was carried out after 6 months of use and after 1742 injections. Fresh solvent was used each time. Results show an overall \% RSD below 6 for the CO6980v0c22 gp145 concentrations of 12.5, 25, 37.5, 50, $75100 \mu \mathrm{g} / \mathrm{ml}$ (Table 5). The overall percent RSD observed for variations in the guard column lots and temperature $\left(78,80\right.$ and $\left.82^{\circ} \mathrm{C}\right)$ were $1.14 \%$ and $1.11 \%$, respectively (Table 6 and 7 ).. Moreover, stability analysis shows that CO6980v0c22 gp145 solutions are stable for 4 days at $100 \mathrm{C}$ with an overall \% RSD of $2.73 \%$ (Table 8 ).

\section{Quantitation of HIV-1 CO6980v0c22 gp145 from bioreactors}

We tested the newly developed RP-HPLC method with actual supernatants from a bioreactor run. Samples of supernatant from CHO-K1 cells expressing CO6980v0c22 gp145 were removed daily from a 40L bioreactor and diluted in 50\% D-PBS and analyzed by RP-HPLC and western blot. The results from both methods are presented in Figure 3. The concentration estimates obtained by western blot were consistently higher than the RP-HPLC measurements. However, the concentrations measurements by RP-HPLC were performed in triplicates and the average standard deviation was determined to be less than $4 \%$ of the total value.

\section{Discussion}

The production of protein-based vaccines in bioreactors requires the development of methods for the quantitation of the desired product, that are quick, highly selective, accurate, reproducible, and that require minimal sample processing. The production of HIV Env vaccines has mainly employed ELISA for the quantification of vaccine products secreted onto the cultivation media. While ELISA is inexpensive and relatively easy to implement in any production setting, the waiting times for ELISA incubations and washes can be long and the variability of the measurement can often be too wide for the method to be considered accurate (H. G. Hansen et al., 2016). Another method for the detection and quantitation of protein products in crude supernatants is the western blot, which also depends on the recognition of the protein analyte by a primary antibody. The high variability associated with both ELISA and western blot may arise from their reliance on the binding of antibody:enzyme conjugates (Janes 2015).

Here, we report a RP-HPLC method for the specific quantification of an HIV-1 CO6980v0c22 gp145 vaccine candidate directly in culture supernatants of CHO-K1 cells that does not rely on antibody binding. The method described herein was found to be linear within a broad range of concentrations, with a relative variability within $3 \%$, and an average recovery of $101 \%$. The method was accurate, with $2.7 \%$ variability on consecutive measurements. The method was precise, with an inter-day variability of $0.34 \%$ and an inter-user variability of $1.5 \%$ for two different users. The method was also found to be robust, as the measurements obtained with a 6 -month old column (after 1742 injections) were within $5.4 \%-1.6 \%$ of the measurements obtained with a new column. The use of different guard columns did not greatly affect separation, since the guard column variability was found to be $1.1 \%$. Finally, the same measurement was carried out with a standard that had been left at $10^{\circ} \mathrm{C}$ for 3 days and the measurements differed by less than $2.7 \%$, providing a first insight into the stability of this highly glycosylated family of vaccines.

A direct comparison between the RP-HPLC method and western blot indicates that our method is suitable for the determination, with low variability, of protein concentration in a bioreactor (Figure 3). Our RP-HPLC method registered the daily increase in the concentration of CO6980v0c22 gp145 in the bioreactor, with a 
variability of approximately $4 \%$ of the total value. The western blot method, however, consistently gave higher concentration values, a commonly observed phenomenon for which we have no explanation, although the limitations of the western blot as a quantitative technique have been extensively reported (Janes, 2015).

In all, we have presented the development of a RP-HPLC method for the detection and quantification of HIV-1 CO6980v0c22 gp145 in CHO-K1 culture supernatants. This method could be easily adapted for the analysis of other glycoproteins made in mammalian cell systems. Our method was determined to be accurate, precise, robust, and required a running time of 15 minutes per sample, substantially shorter than the time needed for an ELISA measurement.

\section{Acknowledgements}

This work was supported by National Institutes of Health (NIH) grant 5R01AI122935-02 to JAL-D and AB-O. Some of the shared instrumentation was purchased with NIH Grant G12RR03051 (RCMI Program). The authors thank Dr. Edgard Resto from the University of Puerto Rico Materials Characterization Center for discussion and critical reading of the manuscript. The authors thank Advanced Biosciences Laboratories, Inc. for providing the CO6980v0c22 gp145 reference materials. The HIV-1 SF162 gp140 trimer recombinant protein was obtained through the NIH AIDS Reagent Program, Division of AIDS, NIAID, NIH: HIV-1 SF162 gp140 trimer, from Dr. Leo Stamatatos.

\section{References}

Aldon, Y., McKay, P. F., Allen, J., Ozorowski, G., Felfödiné Lévai, R., Tolazzi, M., Rogers, P., He, L., de Val, N., Fábián, K., Scarlatti, G., Zhu, J., Ward, A. B., Crispin, M., \& Shattock, R. J. (2018). Rational Design of DNA-Expressed Stabilized Native-Like HIV-1 Envelope Trimers.Cell Reports , 24 (12), 3324-3338.e5. https://doi.org/10.1016/j.celrep.2018.08.051

Bale, S., Martiné, A., Wilson, R., Behrens, A.-J., Le Fourn, V., de Val, N., Sharma, S. K., Tran, K., Torres, J. L., Girod, P.-A., Ward, A. B., Crispin, M., \& Wyatt, R. T. (2018). Cleavage-Independent HIV-1 Trimers From CHO Cell Lines Elicit Robust Autologous Tier 2 Neutralizing Antibodies. Frontiers in Immunology , 9, 1116. https://doi.org/10.3389/fimmu.2018.01116

Berman, P. W., Gregory, T. J., Riddle, L., Nakamura, G. R., Champe, M. A., Porter, J. P., Wurm, F. M., Hershberg, R. D., Cobb, E. K., \& Eichberg, J. W. (1990). Protection of chimpanzees from infection by HIV-1 after vaccination with recombinant glycoprotein gp120 but not gp160. Nature , 345 (6276), 622-625. https://doi.org/10.1038/345622a0

Cheng-Mayer C, Weiss C, Seto D, and Levy JA. (1989) Isolates of human immunodeficiency

virus type 1 from the brain may constitute a special group of the AIDS virus. Proc Natl Acad Sci US A. $86(21): 8575-9$.

Chung, N. P. Y., Matthews, K., Kim, H. J., Ketas, T. J., Golabek, M., de Los Reyes, K., Korzun, J., Yasmeen, A., Sanders, R. W., Klasse, P. J., Wilson, I. A., Ward, A. B., Marozsan, A. J., Moore, J. P., \& Cupo, A. (2014). Stable $293 \mathrm{~T}$ and CHO cell lines expressing cleaved, stable HIV-1 envelope glycoprotein trimers for structural and vaccine studies.Retrovirology , 11 , 33. https://doi.org/10.1186/1742-4690-11-33

Dey, A. K., Cupo, A., Ozorowski, G., Sharma, V. K., Behrens, A.-J., Go, E. P., Ketas, T. J., Yasmeen, A., Klasse, P. J., Sayeed, E., Desaire, H., Crispin, M., Wilson, I. A., Sanders, R. W., Hassell, T., Ward, A. B., \& Moore, J. P. (2018). CGMP production and analysis of BG505 SOSIP.664, an extensively glycosylated, trimeric HIV-1 envelope glycoprotein vaccine candidate. Biotechnology and Bioengineering ,115 (4), 885-899. https://doi.org/10.1002/bit.26498

Easterhoff, D., Moody, M. A., Fera, D., Cheng, H., Ackerman, M., Wiehe, K., Saunders, K. O., Pollara, J., Vandergrift, N., Parks, R., Kim, J., Michael, N. L., O'Connell, R. J., Excler, J.-L., Robb, M. L., Vasan, S., Rerks-Ngarm, S., Kaewkungwal, J., Pitisuttithum, P., .. Haynes, B. F. (2017). Boosting of HIV envelope CD4 binding site antibodies with long variable heavy third complementarity determining 
region in the randomized double blind RV305 HIV-1 vaccine trial. PLoS Pathogens , 13 (2), e1006182. https://doi.org/10.1371/journal.ppat.1006182

Fenouillet, E., Papandréou, M. J., \& Jones, I. M. (1997). Recombinant HIV envelope expressed in an alphaglucosidase I-deficient $\mathrm{CHO}$ cell line and its parental cell line in the presence of 1-deoxynojirimycin is functional. Virology , 231 (1), 89-95. https://doi.org/10.1006/viro.1997.8505

Gray, G. E., Andersen-Nissen, E., Grunenberg, N., Huang, Y., Roux, S., Laher, F., Innes, C., Gu, N., DiazGranados, C., Phogat, S., Lee, C., Swann, E., Kim, J., O'Connell, R., Michael, N., Flach, B., DeRosa, S., Frahm, N., Morris, L., ... HVTN 097. (2014). HVTN 097: Evaluation of the RV144 Vaccine Regimen in HIV Uninfected South African Adults.AIDS Research and Human Retroviruses , 30 (S1), A33-A34. https://doi.org/10.1089/aid.2014.5052a.abstract

González-Feliciano, JA; Akamine, P; Coral M. Capó-Vélez, CM; Delgado-Vélez, M; Dussupt, V; Krebs, SJ; Wojna, V; Polonis, VR; Baerga-Ortiz, A; and Lasalde-Dominicci, JA. (2020) A recombinant gp145 Env glycoprotein from HIV-1 expressed in two different cell lines: effects on glycosylation and antigenicity. PLOS ONE 15(6): e0231679. https://doi.org/10.1371/journal.pone.0231679

Guenaga, J., Dubrovskaya, V., Val, N. de, Sharma, S. K., Carrette, B., Ward, A. B., \& Wyatt, R. T. (2016). Structure-Guided Redesign Increases the Propensity of HIV Env To Generate Highly Stable Soluble Trimers. Journal of Virology , 90 (6), 2806-2817. https://doi.org/10.1128/JVI.02652-15

Hansen, H. G., Kildegaard, H. F., Lee, G. M., \& Kol, S. (2016). Case study on human $\alpha 1$-antitrypsin: Recombinant protein titers obtained by commercial ELISA kits are inaccurate. Biotechnology Journal ,11 (12), 1648-1656. https://doi.org/10.1002/biot.201600409

Hansen, S. B., Sulzenbacher, G., Huxford, T., Marchot, P., Taylor, P., \& Bourne, Y. (2005). Structures of Aplysia AChBP complexes with nicotinic agonists and antagonists reveal distinctive binding interfaces and conformations. The EMBO Journal , 24 (20), 3635-3646. https://doi.org/10.1038/sj.emboj.7600828

Harper, K. N. (2017). HVTN100 phase $1 / 2$ vaccine trial results promising; phase $2 \mathrm{~b} / 3$ trial to commence. AIDS (London, England) ,31 (2), N1-N2. https://doi.org/10.1097/QAD.0000000000001296

Ho, D. D., Sarngadharan, M. G., Hirsch, M. S., Schooley, R. T., Rota, T. R., Kennedy, R. C., Chanh, T. C., \& Sato, V. L. (1987). Human immunodeficiency virus neutralizing antibodies recognize several conserved domains on the envelope glycoproteins. Journal of Virology ,61 (6), 2024-2028.

ICH harmonized tripartite guidline, Validation of analytical procedures: text and

methodology, Q2 (R1), Current Step 4th version, Parent guidelines on Methodology

Dated November 6, 1996, Incorporated in November 2005

Janes, K. A. (2015) An analysis of critical factors for quantitative immunoblotting. Sci

Signal. 8(371):rs2.

Kovacs, J. M., Nkolola, J. P., Peng, H., Cheung, A., Perry, J., Miller, C. A., Seaman, M. S., Barouch, D. H., \& Chen, B. (2012). HIV-1 envelope trimer elicits more potent neutralizing antibody responses than monomeric gp120. Proceedings of the National Academy of Sciences of the United States of America, 109 (30), 12111-12116. https://doi.org/10.1073/pnas.1204533109

O'Rourke, S. M., Byrne, G., Tatsuno, G., Wright, M., Yu, B., Mesa, K. A., Doran, R. C., Alexander, D., \& Berman, P. W. (2018). Robotic selection for the rapid development of stable CHO cell lines for HIV vaccine production. PloS One, 13 (8), e0197656. https://doi.org/10.1371/journal.pone.0197656

Pantophlet, R., \& Burton, D. R. (2006). GP120: Target for neutralizing HIV-1 antibodies. Annual Review of Immunology , 24 , 739-769. https://doi.org/10.1146/annurev.immunol.24.021605.090557 
Rerks-Ngarm, S., Pitisuttithum, P., Nitayaphan, S., Kaewkungwal, J., Chiu, J., Paris, R., Premsri, N., Namwat, C., de Souza, M., Adams, E., Benenson, M., Gurunathan, S., Tartaglia, J., McNeil, J. G., Francis, D. P., Stablein, D., Birx, D. L., Chunsuttiwat, S., Khamboonruang, C., .. MOPH-TAVEG Investigators. (2009). Vaccination with ALVAC and AIDSVAX to prevent HIV-1 infection in Thailand. The New England Journal of Medicine , 361 (23), 2209-2220. https://doi.org/10.1056/NEJMoa0908492

Sanders, R. W., \& Moore, J. P. (2017). Native-like Env trimers as a platform for HIV-1 vaccine design. Immunological Reviews ,275 (1), 161-182. https://doi.org/10.1111/imr.12481

Sanders, R. W., Vesanen, M., Schuelke, N., Master, A., Schiffner, L., Kalyanaraman, R., Paluch, M., Berkhout, B., Maddon, P. J., Olson, W. C., Lu, M., \& Moore, J. P. (2002). Stabilization of the soluble, cleaved, trimeric form of the envelope glycoprotein complex of human immunodeficiency virus type 1. Journal of Virology ,76 (17), 8875-8889. https://doi.org/10.1128/jvi.76.17.8875-8889.2002

Sellhorn G, Caldwell Z, Mineart C, and Stamatatos L. (2009) Improving the expression of recombinant soluble HIV Envelope glycoproteins using pseudo-stable transient transfection. Vaccine. 28(2):430-6

Stamatatos L, Wiskerchen M, Cheng-Mayer C. (1998) Effect of major deletions in the V1

and V2 loops of a macrophage-tropic HIV type 1 isolate on viral envelope structure, cell entry, and replication. AIDS Res Hum Retroviruses. 14(13):1129-39.

Stamatatos L, Lim M, Cheng-Mayer C. (2000) Generation and structural analysis of soluble

oligomeric gp140 envelope proteins derived from neutralization-resistant and neutralization-susceptible primary HIV type 1 isolates. AIDS Res Hum Retroviruses. 16(10):981-94.

Weiss, C. D., \& White, J. M. (1993). Characterization of stable Chinese hamster ovary cells expressing wildtype, secreted, and glycosylphosphatidylinositol-anchored human immunodeficiency virus type 1 envelope glycoprotein. Journal of Virology , 67 (12), 7060-7066.

Wieczorek, L., Krebs, S. J., Kalyanaraman, V., Whitney, S., Tovanabutra, S., Moscoso, C. G., SandersBuell, E., Williams, C., Slike, B., Molnar, S., Dussupt, V., Alam, S. M., Chenine, A.-L., Tong, T., Hill, E. L., Liao, H.-X., Hoelscher, M., Maboko, L., Zolla-Pazner, S., .. Polonis, V. R. (2015). Comparable Antigenicity and Immunogenicity of Oligomeric Forms of a Novel, Acute HIV-1 Subtype C gp145 Envelope for Use in Preclinical and Clinical Vaccine Research. Journal of Virology , 89 (15), 7478-7493. https://doi.org/10.1128/JVI.00412-15

Wintsch, J., Chaignat, C. L., Braun, D. G., Jeannet, M., Stalder, H., Abrignani, S., Montagna, D., Clavijo, F., Moret, P., \& Dayer, J. M. (1991). Safety and immunogenicity of a genetically engineered human immunodeficiency virus vaccine. The Journal of Infectious Diseases , 163 (2), 219-225. https://doi.org/10.1093/infdis/163.2.219

\section{Conflict of Interest}

The authors declare that they have no conflict of interest with the content of this article.

Table 1. Retention parameters of the to HIV-1 env proteins in this study. Table 1. Retention parameters of the to HIV-1

\begin{tabular}{ll}
\hline Sample & Retention time (average, minutes) \\
CO6980v0c22 gp145 & 5.385 \\
SF162 gp140 & 5.489 \\
\hline
\end{tabular}

Table 2. Validation parameters for the RP-HPLC analysis of CO6980v0c22 gp145 


\begin{tabular}{ll}
\hline Table 2. Validation parameters for the RP-HPLC analysis of CO6980v0c22 gp145 & Table 2. Validation parameters for the \\
\hline Concentration Range & $12.5-100 \mu \mathrm{g} / \mathrm{ml}$ \\
Intercept & 17.79 \\
Correlation Coefficient & 0.9996 \\
Standard Error of Intercept & 3.184 \\
Standard Deviation of Intercept & 7.8 \\
Limit of Detection (LOD) & 2.4 \\
Limit of Quantitation (LOQ) & 7.1 \\
\hline
\end{tabular}

\begin{tabular}{|c|c|c|c|c|c|c|}
\hline $\begin{array}{l}\text { Table } 3 . \\
\text { Accuracy of } \\
\text { the } \\
\text { RP-HPLC } \\
\text { method for } \\
\text { the } \\
\text { quantitation } \\
\text { of } \\
\text { CO6980v0c22 } \\
\text { gp145. }\end{array}$ & $\begin{array}{l}\text { Table } 3 . \\
\text { Accuracy of } \\
\text { the } \\
\text { RP-HPLC } \\
\text { method for } \\
\text { the } \\
\text { quantitation } \\
\text { of } \\
\text { CO6980v0c } 22 \\
\text { gp145. }\end{array}$ & $\begin{array}{l}\text { Table } 3 . \\
\text { Accuracy of } \\
\text { the } \\
\text { RP-HPLC } \\
\text { method for } \\
\text { the } \\
\text { quantitation } \\
\text { of } \\
\text { CO6980v0c22 } \\
\text { gp145. }\end{array}$ & $\begin{array}{l}\text { Table } 3 . \\
\text { Accuracy of } \\
\text { the } \\
\text { RP-HPLC } \\
\text { method for } \\
\text { the } \\
\text { quantitation } \\
\text { of } \\
\text { CO6980v0c22 } \\
\text { gp145. }\end{array}$ & $\begin{array}{l}\text { Table } 3 . \\
\text { Accuracy of } \\
\text { the } \\
\text { RP-HPLC } \\
\text { method for } \\
\text { the } \\
\text { quantitation } \\
\text { of } \\
\text { CO6980v0c } 22 \\
\text { gp145. }\end{array}$ & $\begin{array}{l}\text { Table } 3 . \\
\text { Accuracy of } \\
\text { the } \\
\text { RP-HPLC } \\
\text { method for } \\
\text { the } \\
\text { quantitation } \\
\text { of } \\
\text { CO6980v0c22 } \\
\text { gp145. }\end{array}$ & $\begin{array}{l}\text { Table } 3 . \\
\text { Accuracy of } \\
\text { the } \\
\text { RP-HPLC } \\
\text { method for } \\
\text { the } \\
\text { quantitation } \\
\text { of } \\
\text { CO6980v0c } 22 \\
\text { gp145. }\end{array}$ \\
\hline $\begin{array}{l}\text { Standard } \\
\text { theoretical } \\
\text { concentration } \\
(\mu \mathrm{g} / \mathrm{ml})\end{array}$ & $\begin{array}{l}\text { Standard } 1 \\
\text { (AUP) } 12.5\end{array}$ & $\begin{array}{l}\text { Standard } 2 \\
\text { (AUP) } 25\end{array}$ & $\begin{array}{l}\text { Standard } 3 \\
\text { (AUP) } 37.5\end{array}$ & $\begin{array}{l}\text { Standard } 4 \\
\text { (AUP) } 50\end{array}$ & $\begin{array}{l}\text { Standard } 5 \\
\text { (AUP) } 75\end{array}$ & $\begin{array}{l}\text { Standard } 6 \\
\text { (AUP) } 100\end{array}$ \\
\hline Replicate 1 & 159.688 & 298.354 & 416.166 & 557.712 & 832.336 & 1113.595 \\
\hline Replicate 2 & 160.957 & 299.258 & 417.580 & 557.202 & 833.186 & 1115.165 \\
\hline Replicate 3 & 162.059 & 285.307 & 419.959 & 558.925 & 835.098 & 1114.760 \\
\hline $\begin{array}{l}\text { Mean of } \\
\text { AUP }\end{array}$ & 160.900 & 294.310 & 417.900 & 557.950 & 833.540 & 1114.510 \\
\hline$\%$ RSD & 0.74 & 2.65 & 0.46 & 0.16 & 0.17 & 0.07 \\
\hline $\begin{array}{l}\text { Calculated } \\
\text { concentra- } \\
\text { tion } \\
(\mu \mathrm{g} / \mu \mathrm{l})\end{array}$ & 13.1 & 25.3 & 36.7 & 49.5 & 74.8 & 100.5 \\
\hline$\%$ Recovery & 104.9 & 101.4 & 97.8 & 99.0 & 99.7 & 100.5 \\
\hline $\begin{array}{l}\text { \% Recovery } \\
\text { average: }\end{array}$ & $\begin{array}{l}\text { \% Recovery } \\
\text { average: }\end{array}$ & $\begin{array}{l}\text { \% Recovery } \\
\text { average: }\end{array}$ & $\begin{array}{l}\text { \% Recovery } \\
\text { average: }\end{array}$ & $\begin{array}{l}\text { \% Recovery } \\
\text { average: }\end{array}$ & $\begin{array}{l}\text { \% Recovery } \\
\text { average: }\end{array}$ & $\begin{array}{l}\text { \% Recovery } \\
\text { average: }\end{array}$ \\
\hline $\begin{array}{l}\text { 100.56, } \\
\text { STDEV: }\end{array}$ & $\begin{array}{l}\text { 100.56, } \\
\text { STDEV: }\end{array}$ & $\begin{array}{l}\text { 100.56, } \\
\text { STDEV: }\end{array}$ & $\begin{array}{l}\text { 100.56, } \\
\text { STDEV: }\end{array}$ & $\begin{array}{l}\text { 100.56, } \\
\text { STDEV: }\end{array}$ & $\begin{array}{l}\text { 100.56, } \\
\text { STDEV: }\end{array}$ & $\begin{array}{l}\text { 100.56, } \\
\text { STDEV: }\end{array}$ \\
\hline $\begin{array}{l}2.44, \% \text { RSD: } \\
2.42\end{array}$ & $\begin{array}{l}2.44, \% \mathrm{RSD}: \\
2.42\end{array}$ & $\begin{array}{l}2.44, \% \mathrm{RSD}: \\
2.42\end{array}$ & $\begin{array}{l}2.44, \% \mathrm{RSD}: \\
2.42\end{array}$ & $\begin{array}{l}2.44, \% \mathrm{RSD}: \\
2.42\end{array}$ & $\begin{array}{l}2.44, \% \text { RSD: } \\
2.42\end{array}$ & $\begin{array}{l}2.44, \% \mathrm{RSD}: \\
2.42\end{array}$ \\
\hline
\end{tabular}




\begin{tabular}{|c|c|c|c|c|c|c|}
\hline $\begin{array}{l}\text { able } 3 . \\
\text { ccuracy of } \\
\text { e } \\
\text { P-HPLC } \\
\text { ethod for } \\
\text { ne } \\
\text { uantitation } \\
\text { O6980v0c22 } \\
145 .\end{array}$ & $\begin{array}{l}\text { Table } 3 . \\
\text { Accuracy of } \\
\text { the } \\
\text { RP-HPLC } \\
\text { method for } \\
\text { the } \\
\text { quantitation } \\
\text { of } \\
\text { CO6980v0c22 } \\
\text { gp145. }\end{array}$ & $\begin{array}{l}\text { able } 3 . \\
\text { ccuracy of } \\
\text { e } \\
\text { P-HPLC } \\
\text { ethod for } \\
\text { he } \\
\text { dantitation } \\
\text { O6980v0c } 22 \\
145 .\end{array}$ & $\begin{array}{l}\text { ble } 3 . \\
\text { curacy of } \\
\text { e } \\
\text {-HPLC } \\
\text { thod for } \\
\text { e } \\
\text { antitation } \\
\\
145 \text {. }\end{array}$ & $\begin{array}{l}\text { able } 3 . \\
\text { ccuracy of } \\
\text { e } \\
\text { P-HPLC } \\
\text { ethod for } \\
\text { e } \\
\text { lantitation } \\
\text { O6980v0c22 } \\
145 .\end{array}$ & $\begin{array}{l}\text { ble } 3 \text {. } \\
\text { curacy of } \\
\text {-HPLC } \\
\text { thod for } \\
\text { antitation } \\
\\
6980 \mathrm{v} 0 \mathrm{c} 22 \\
145 \text {. }\end{array}$ & $\begin{array}{l}\text { ble } 3 \text {. } \\
\text { curacy of } \\
\text { e } \\
\text { a-HPLC } \\
\text { ethod for } \\
\text { antitation } \\
\\
145980 \text { v0c22 } \\
\end{array}$ \\
\hline $\begin{array}{l}\text { The area } \\
\text { under the } \\
\text { eak (AUP) } \\
\text { vas } \\
\text { neasured for } \\
\text { standards, } \\
\text { ach } \\
\text { repared } \\
\text { rom a } \\
\text { nnown con- } \\
\text { entration of } \\
\text { he reference } \\
\text { naterial. } \\
\text { Each point } \\
\text { vas } \\
\text { letermined } \\
\text { n riplicates. } \\
\text { Recovery is } \\
\text { xpressed as: } \\
\text { calculated }\end{array}$ & $\begin{array}{l}\text { The area } \\
\text { under the } \\
\text { peak (AUP) } \\
\text { was } \\
\text { measured for } \\
6 \text { standards, } \\
\text { each } \\
\text { prepared } \\
\text { from a } \\
\text { known con- } \\
\text { centration of } \\
\text { the reference } \\
\text { material. } \\
\text { Each point } \\
\text { was } \\
\text { determined } \\
\text { in } \\
\text { triplicates. } \\
\text { Recovery is } \\
\text { expressed as: } \\
\text { (calculated } \\
\text { conc./theoretical } \\
\text { conc.)*100. }\end{array}$ & $\begin{array}{l}\text { The area } \\
\text { under the } \\
\text { peak (AUP) } \\
\text { was } \\
\text { measured for } \\
6 \text { standards, } \\
\text { each } \\
\text { prepared } \\
\text { from a } \\
\text { known con- } \\
\text { centration of } \\
\text { the reference } \\
\text { material. } \\
\text { Each point } \\
\text { was } \\
\text { determined } \\
\text { in } \\
\text { triplicates. } \\
\text { Recovery is } \\
\text { expressed as: } \\
\text { (calculated } \\
\text { conc./theoretical } \\
\text { conc.)*100. }\end{array}$ & $\begin{array}{l}\text { The area } \\
\text { under the } \\
\text { peak (AUP) } \\
\text { was } \\
\text { measured for } \\
6 \text { standards, } \\
\text { each } \\
\text { prepared } \\
\text { from a } \\
\text { known con- } \\
\text { centration of } \\
\text { the reference } \\
\text { material. } \\
\text { Each point } \\
\text { was } \\
\text { determined } \\
\text { in } \\
\text { triplicates. } \\
\text { Recovery is } \\
\text { expressed as: } \\
\text { (calculated } \\
\text { conc./theoretical } \\
\text { conc.)*100. }\end{array}$ & $\begin{array}{l}\text { The area } \\
\text { under the } \\
\text { peak (AUP) } \\
\text { was } \\
\text { measured for } \\
6 \text { standards, } \\
\text { each } \\
\text { prepared } \\
\text { from a } \\
\text { known con- } \\
\text { centration of } \\
\text { the reference } \\
\text { material. } \\
\text { Each point } \\
\text { was } \\
\text { determined } \\
\text { in } \\
\text { triplicates. } \\
\text { Recovery is } \\
\text { expressed as: } \\
\text { (calculated } \\
\text { conc./theoretical } \\
\text { conc.)*100. }\end{array}$ & $\begin{array}{l}\text { The area } \\
\text { under the } \\
\text { peak (AUP) } \\
\text { was } \\
\text { measured for } \\
6 \text { standards, } \\
\text { each } \\
\text { prepared } \\
\text { from a } \\
\text { known con- } \\
\text { centration of } \\
\text { the reference } \\
\text { material. } \\
\text { Each point } \\
\text { was } \\
\text { determined } \\
\text { in } \\
\text { triplicates. } \\
\text { Recovery is } \\
\text { expressed as: } \\
\text { (calculated } \\
\text { conc./theoretical } \\
\text { conc.)*100. }\end{array}$ & $\begin{array}{l}\text { The area } \\
\text { under the } \\
\text { peak (AUP) } \\
\text { was } \\
\text { measured for } \\
6 \text { standards, } \\
\text { each } \\
\text { prepared } \\
\text { from a } \\
\text { known con- } \\
\text { centration of } \\
\text { the reference } \\
\text { material. } \\
\text { Each point } \\
\text { was } \\
\text { determined } \\
\text { in } \\
\text { triplicates. } \\
\text { Recovery is } \\
\text { expressed as: } \\
\text { (calculated } \\
\text { conc./theoretic } \\
\text { conc.)*100. }\end{array}$ \\
\hline
\end{tabular}

\begin{tabular}{|c|c|c|}
\hline $\begin{array}{l}\text { Table 4. Precision of the } \\
\text { RP-HPLC method for the } \\
\text { quantitation of CO6980v0c } 22 \\
\text { gp145 }\end{array}$ & $\begin{array}{l}\text { Table } 4 \text {. Precision of the } \\
\text { RP-HPLC method for the } \\
\text { quantitation of CO6980v0c } 22 \\
\text { gp145 }\end{array}$ & $\begin{array}{l}\text { Table } 4 \text {. Precision of the } \\
\text { RP-HPLC method for the } \\
\text { quantitation of CO6980v0c } 22 \\
\text { gp145 }\end{array}$ \\
\hline $\begin{array}{l}\text { Standard theoretical } \\
\text { concentration }(\mu \mathrm{g} / \mathrm{ml})\end{array}$ & $\begin{array}{l}\text { User \#1 } \\
\text { Standard } 1 \text { (AUP) } 60\end{array}$ & $\begin{array}{l}\text { User \#2 } \\
\text { Standard } 2 \text { (AUP) } 60\end{array}$ \\
\hline Replicate 1 & 669.39 & 683.508 \\
\hline Replicate 2 & 667.60 & 684.305 \\
\hline Replicate 3 & 665.96 & 681.727 \\
\hline Replicate 4 & 670.87 & 684.493 \\
\hline Replicate 5 & 671.88 & 684.057 \\
\hline Replicate 6 & 667.13 & 682.474 \\
\hline Average & 668.80 & 683.43 \\
\hline $\begin{array}{l}\text { Calculated Concentration } \\
(\mu \mathrm{g} / \mathrm{ml})\end{array}$ & 59.660 & 60.872 \\
\hline
\end{tabular}




\begin{tabular}{|c|c|c|}
\hline $\begin{array}{l}\text { Table 4. Precision of the } \\
\text { RP-HPLC method for the } \\
\text { quantitation of CO6980v0c } 22 \\
\text { gp145 }\end{array}$ & $\begin{array}{l}\text { Table 4. Precision of the } \\
\text { RP-HPLC method for the } \\
\text { quantitation of CO6980v0c } 22 \\
\text { gp145 }\end{array}$ & $\begin{array}{l}\text { Table 4. Precision of the } \\
\text { RP-HPLC method for the } \\
\text { quantitation of CO6980v0c } 22 \\
\text { gp145 }\end{array}$ \\
\hline $\begin{array}{l}\% \text { Recovery } \\
\% \text { RSD } \\
\text { Overall \% RSD } \\
\text { Two different users performed } \\
\text { the injection of a } 60 \mu \mathrm{g} / \mathrm{ml} \text { six } \\
\text { times. User \#1 performed all } \\
\text { injections on the same day, and } \\
\text { User \# } 2 \text { performed the } \\
\text { injections on a different day. } \\
\text { The overall \% RSD is the } \\
\text { relative standard deviation of } \\
\text { all injections performed. }\end{array}$ & $\begin{array}{l}99.43 \\
0.34 \\
1.53 \\
\text { Two different users performed } \\
\text { the injection of a } 60 \mu \mathrm{g} / \mathrm{ml} \text { six } \\
\text { times. User \# } 1 \text { performed all } \\
\text { injections on the same day, and } \\
\text { User \#2 performed the } \\
\text { injections on a different day. } \\
\text { The overall \% RSD is the } \\
\text { relative standard deviation of } \\
\text { all injections performed. }\end{array}$ & $\begin{array}{l}101.45 \\
1.53 \\
1.53 \\
\text { Two different users performed } \\
\text { the injection of a } 60 \mu \mathrm{g} / \mathrm{ml} \text { six } \\
\text { times. User \#1 performed all } \\
\text { injections on the same day, and } \\
\text { User \#2 performed the } \\
\text { injections on a different day. } \\
\text { The overall \% RSD is the } \\
\text { relative standard deviation of } \\
\text { all injections performed. }\end{array}$ \\
\hline
\end{tabular}

\begin{tabular}{|c|c|c|c|c|c|c|c|}
\hline $\begin{array}{l}\text { Table } 5 . \\
\text { Robust- } \\
\text { ness } \\
\text { (column } \\
\text { ageing) of } \\
\text { the } \\
\text { RP-HPLC } \\
\text { method } \\
\text { for } \\
\text { CO6980v0c22 } \\
\text { gp145. }\end{array}$ & $\begin{array}{l}\text { Table } 5 . \\
\text { Robust- } \\
\text { ness } \\
\text { (column } \\
\text { ageing) of } \\
\text { the } \\
\text { RP-HPLC } \\
\text { method } \\
\text { for } \\
\text { CO6980v0c22 } \\
\text { gp145. }\end{array}$ & $\begin{array}{l}\text { Table } 5 . \\
\text { Robust- } \\
\text { ness } \\
\text { (column } \\
\text { ageing) of } \\
\text { the } \\
\text { RP-HPLC } \\
\text { method } \\
\text { for } \\
\text { CO6980v0c22 } \\
\text { gp145. }\end{array}$ & $\begin{array}{l}\text { Table } 5 . \\
\text { Robust- } \\
\text { ness } \\
\text { (column } \\
\text { ageing) of } \\
\text { the } \\
\text { RP-HPLC } \\
\text { method } \\
\text { for } \\
\text { CO6980v0c22 } \\
\text { gp145. }\end{array}$ & $\begin{array}{l}\text { Table } 5 . \\
\text { Robust- } \\
\text { ness } \\
\text { (column } \\
\text { ageing) of } \\
\text { the } \\
\text { RP-HPLC } \\
\text { method } \\
\text { for } \\
\text { CO6980v0c22 } \\
\text { gp145. }\end{array}$ & $\begin{array}{l}\text { Table } 5 . \\
\text { Robust- } \\
\text { ness } \\
\text { (column } \\
\text { ageing) of } \\
\text { the } \\
\text { RP-HPLC } \\
\text { method } \\
\text { for } \\
\text { CO6980v0c22 } \\
\text { gp145. }\end{array}$ & $\begin{array}{l}\text { Table } 5 . \\
\text { Robust- } \\
\text { ness } \\
\text { (column } \\
\text { ageing) of } \\
\text { the } \\
\text { RP-HPLC } \\
\text { method } \\
\text { for } \\
\text { CO6980v0c22 } \\
\text { gp145. }\end{array}$ & $\begin{array}{l}\text { Table } 5 . \\
\text { Robust- } \\
\text { ness } \\
\text { (column } \\
\text { ageing) of } \\
\text { the } \\
\text { RP-HPLC } \\
\text { method } \\
\text { for } \\
\text { CO6980v0c22 } \\
\text { gp145. }\end{array}$ \\
\hline $\begin{array}{l}\text { Concentratio } \\
\text { of gp145 } \\
\text { standard }\end{array}$ & $\begin{array}{l}\text { nAUP } \\
\text { Month } 1\end{array}$ & $\begin{array}{l}\text { Mean of } \\
\text { AUP }\end{array}$ & $\%$ RSD & $\begin{array}{l}\text { AUP } \\
\text { Month } 6\end{array}$ & $\begin{array}{l}\text { Mean of } \\
\text { AUP }\end{array}$ & $\%$ RSD & $\begin{array}{l}\text { Overall } \\
\text { \%RSD }\end{array}$ \\
\hline $\begin{array}{l}12.5 \\
\mu \mathrm{g} / \mathrm{ml}\end{array}$ & $\begin{array}{l}160.957 \\
162.059\end{array}$ & 160.90 & 0.74 & $\begin{array}{l}148.379 \\
149.275 \\
149.320\end{array}$ & 148.99 & 0.36 & 5.44 \\
\hline $25 \mu \mathrm{g} / \mathrm{ml}$ & $\begin{array}{l}298.354 \\
299.258 \\
285.307\end{array}$ & 294.31 & 2.65 & $\begin{array}{l}278.774 \\
280.368 \\
279.369\end{array}$ & 279.50 & 0.29 & 3.65 \\
\hline $\begin{array}{l}37.5 \\
\mu \mathrm{g} / \mathrm{ml}\end{array}$ & $\begin{array}{l}416.166 \\
417.58 \\
419.959\end{array}$ & 417.90 & 0.46 & $\begin{array}{l}411.009 \\
411.727 \\
406.483\end{array}$ & 409.74 & 0.69 & 1.39 \\
\hline $50 \mu \mathrm{g} / \mathrm{ml}$ & $\begin{array}{l}557.712 \\
557.202 \\
558.925\end{array}$ & 557.95 & 0.16 & $\begin{array}{l}552.539 \\
551.055 \\
558.947\end{array}$ & 554.18 & 0.76 & 0.48 \\
\hline $75 \mu \mathrm{g} / \mathrm{ml}$ & $\begin{array}{l}832.336 \\
833.186 \\
835.098\end{array}$ & 833.54 & 0.17 & $\begin{array}{l}824.642 \\
820.339 \\
815.179\end{array}$ & 820.05 & 0.58 & 1.15 \\
\hline $100 \mu \mathrm{g} / \mathrm{ml}$ & 1113.595 & 1114.51 & 0.07 & 1089.800 & 1089.88 & 0.31 & 1.64 \\
\hline
\end{tabular}




\begin{tabular}{|c|c|c|c|c|c|c|c|}
\hline Table 5. & Table 5. & Table 5. & Table 5. & Table 5. & Table 5. & Table 5. & Table 5. \\
\hline Robust- & Robust- & Robust- & Robust- & Robust- & Robust- & Robust- & Robust- \\
\hline ness & ness & ness & ness & ness & ness & ness & ness \\
\hline (column & (column & (column & (column & (column & (column & (column & (column \\
\hline $\begin{array}{l}\text { ageing) of } \\
\text { the }\end{array}$ & $\begin{array}{l}\text { ageing) of } \\
\text { the }\end{array}$ & $\begin{array}{l}\text { ageing) of } \\
\text { the }\end{array}$ & $\begin{array}{l}\text { ageing) of } \\
\text { the }\end{array}$ & $\begin{array}{l}\text { ageing) of } \\
\text { the }\end{array}$ & $\begin{array}{l}\text { ageing) of } \\
\text { the }\end{array}$ & $\begin{array}{l}\text { ageing) of } \\
\text { the }\end{array}$ & $\begin{array}{l}\text { ageing) of } \\
\text { the }\end{array}$ \\
\hline RP-HPLC & RP-HPLC & RP-HPLC & RP-HPLC & RP-HPLC & RP-HPLC & RP-HPLC & RP-HPLC \\
\hline method & method & method & method & method & method & method & method \\
\hline & for & for & for & for & for & for & for \\
\hline $\begin{array}{l}\text { CO6980v0c22 } \\
\text { gp145. }\end{array}$ & $\begin{array}{l}\text { CO6980v0c22 } \\
\text { gp145. }\end{array}$ & $\begin{array}{l}\text { CO6980v0c22 } \\
\text { gp145. }\end{array}$ & $\begin{array}{l}\text { CO6980v0c22 } \\
\text { gp145. }\end{array}$ & $\begin{array}{l}\text { CO6980v0c22 } \\
\text { gp145. }\end{array}$ & $\begin{array}{l}\text { CO6980v0c22 } \\
\text { gp145. }\end{array}$ & $\begin{array}{l}\text { CO6980v0c22 } \\
\text { gp145. }\end{array}$ & $\begin{array}{l}\text { CO6980v0c22 } \\
\text { gp145. }\end{array}$ \\
\hline & 1115.165 & & & 1086.568 & & & \\
\hline & 1114.76 & & & 1093.274 & & & \\
\hline Correlation & Correlation & Correlation & Correlation & Correlation & Correlation & Correlation & Correlation \\
\hline $\begin{array}{l}\text { Coeffi- } \\
\text { cient: }\end{array}$ & $\begin{array}{l}\text { Coeffi- } \\
\text { cient: }\end{array}$ & $\begin{array}{l}\text { Coeffi- } \\
\text { cient: }\end{array}$ & $\begin{array}{l}\text { Coeffi- } \\
\text { cient: }\end{array}$ & $\begin{array}{l}\text { Coeffi- } \\
\text { cient: }\end{array}$ & $\begin{array}{l}\text { Coeffi- } \\
\text { cient: }\end{array}$ & $\begin{array}{l}\text { Coeffi- } \\
\text { cient: }\end{array}$ & $\begin{array}{l}\text { Coeffi- } \\
\text { cient: }\end{array}$ \\
\hline Month 1: & Month 1: & Month 1: & Month 1: & Month 1: & Month 1: & Month 1: & Month 1: \\
\hline 0.9996 & 0.9996 & 0.9996 & 0.9996 & 0.9996 & 0.9996 & 0.9996 & 0.9996 \\
\hline Month 2: & Month 2: & Month 2: & Month 2: & Month 2: & Month 2: & Month 2: & Month 2: \\
\hline 0.9998 & 0.9998 & 0.9998 & 0.9998 & 0.9998 & 0.9998 & 0.9998 & 0.9998 \\
\hline
\end{tabular}




\begin{tabular}{|c|c|c|c|c|c|c|c|}
\hline $\begin{array}{l}\text { Table } 5 . \\
\text { Robust- } \\
\text { ness } \\
\text { (column } \\
\text { ageing) of } \\
\text { the } \\
\text { RP-HPLC } \\
\text { method } \\
\text { for } \\
\text { CO6980v0c22 } \\
\text { gp145. }\end{array}$ & $\begin{array}{l}\text { Table } 5 . \\
\text { Robust- } \\
\text { ness } \\
\text { (column } \\
\text { ageing) of } \\
\text { the } \\
\text { RP-HPLC } \\
\text { method } \\
\text { for } \\
\text { CO6980v0c22 } \\
\text { gp145. }\end{array}$ & $\begin{array}{l}\text { Table } 5 . \\
\text { Robust- } \\
\text { ness } \\
\text { (column } \\
\text { ageing) of } \\
\text { the } \\
\text { RP-HPLC } \\
\text { method } \\
\text { for } \\
\text { CO6980v0c22 } \\
\text { gp145. }\end{array}$ & $\begin{array}{l}\text { Table } 5 . \\
\text { Robust- } \\
\text { ness } \\
\text { (column } \\
\text { ageing) of } \\
\text { the } \\
\text { RP-HPLC } \\
\text { method } \\
\text { for } \\
\text { CO6980v0c22 } \\
\text { gp145. }\end{array}$ & $\begin{array}{l}\text { Table } 5 . \\
\text { Robust- } \\
\text { ness } \\
\text { (column } \\
\text { ageing) of } \\
\text { the } \\
\text { RP-HPLC } \\
\text { method } \\
\text { for } \\
\text { CO6980v0c22 } \\
\text { gp145. }\end{array}$ & $\begin{array}{l}\text { Table } 5 . \\
\text { Robust- } \\
\text { ness } \\
\text { (column } \\
\text { ageing) of } \\
\text { the } \\
\text { RP-HPLC } \\
\text { method } \\
\text { for } \\
\text { CO6980v0c22 } \\
\text { gp145. }\end{array}$ & $\begin{array}{l}\text { Table } 5 . \\
\text { Robust- } \\
\text { ness } \\
\text { (column } \\
\text { ageing) of } \\
\text { the } \\
\text { RP-HPLC } \\
\text { method } \\
\text { for } \\
\text { CO6980v0c22 } \\
\text { gp145. }\end{array}$ & $\begin{array}{l}\text { Table } 5 . \\
\text { Robust- } \\
\text { ness } \\
\text { (column } \\
\text { ageing) of } \\
\text { the } \\
\text { RP-HPLC } \\
\text { method } \\
\text { for } \\
\text { CO6980v0c2 } \\
\text { gp145. }\end{array}$ \\
\hline $\begin{array}{l}\text { HPLC } \\
\text { system } \\
\text { remained } \\
\text { in use } \\
\text { between } \\
\text { Month 1 } \\
\text { and } \\
\text { Month 6. } \\
\text { The } \\
\text { overall \% } \\
\text { RSD is } \\
\text { the } \\
\text { relative } \\
\text { standard } \\
\text { deviation } \\
\text { of all } \\
\text { injections } \\
\text { carried } \\
\text { out for } \\
\text { that } \\
\text { stondord }\end{array}$ & $\begin{array}{l}\text { All } \\
\text { standard } \\
\text { concentra- } \\
\text { tions were } \\
\text { analyzed } \\
\text { in } \\
\text { triplicates } \\
\text { on } \\
\text { different } \\
\text { months. } \\
\text { The } \\
\text { column } \\
\text { and the } \\
\text { HPLC } \\
\text { system } \\
\text { remained } \\
\text { in use } \\
\text { between } \\
\text { Month } 1 \\
\text { and } \\
\text { Month } 6 . \\
\text { The } \\
\text { overall \% } \\
\text { RSD is } \\
\text { the } \\
\text { relative } \\
\text { standard } \\
\text { deviation } \\
\text { of all } \\
\text { injections } \\
\text { carried } \\
\text { out for } \\
\text { that } \\
\text { standard } \\
\text { concentratiol }\end{array}$ & $\begin{array}{l}\text { All } \\
\text { standard } \\
\text { concentra- } \\
\text { tions were } \\
\text { analyzed } \\
\text { in } \\
\text { triplicates } \\
\text { on } \\
\text { different } \\
\text { months. } \\
\text { The } \\
\text { column } \\
\text { and the } \\
\text { HPLC } \\
\text { system } \\
\text { remained } \\
\text { in use } \\
\text { between } \\
\text { Month 1 } \\
\text { and } \\
\text { Month } 6 . \\
\text { The } \\
\text { overall \% } \\
\text { RSD is } \\
\text { the } \\
\text { relative } \\
\text { standard } \\
\text { deviation } \\
\text { of all } \\
\text { injections } \\
\text { carried } \\
\text { out for } \\
\text { that } \\
\text { standard } \\
\text { concentration. }\end{array}$ & $\begin{array}{l}\text { All } \\
\text { standard } \\
\text { concentra- } \\
\text { tions were } \\
\text { analyzed } \\
\text { in } \\
\text { triplicates } \\
\text { on } \\
\text { different } \\
\text { months. } \\
\text { The } \\
\text { column } \\
\text { and the } \\
\text { HPLC } \\
\text { system } \\
\text { remained } \\
\text { in use } \\
\text { between } \\
\text { Month } 1 \\
\text { and } \\
\text { Month } 6 . \\
\text { The } \\
\text { overall \% } \\
\text { RSD is } \\
\text { the } \\
\text { relative } \\
\text { standard } \\
\text { deviation } \\
\text { of all } \\
\text { injections } \\
\text { carried } \\
\text { out for } \\
\text { that } \\
\text { standard } \\
\text { concentration. }\end{array}$ & $\begin{array}{l}\text { All } \\
\text { standard } \\
\text { concentra- } \\
\text { tions were } \\
\text { analyzed } \\
\text { in } \\
\text { triplicates } \\
\text { on } \\
\text { different } \\
\text { months. } \\
\text { The } \\
\text { column } \\
\text { and the } \\
\text { HPLC } \\
\text { system } \\
\text { remained } \\
\text { in use } \\
\text { between } \\
\text { Month } 1\end{array}$ & $\begin{array}{l}\text { All } \\
\text { standard } \\
\text { concentra- } \\
\text { tions were } \\
\text { analyzed } \\
\text { in } \\
\text { triplicates } \\
\text { on } \\
\text { different } \\
\text { months. } \\
\text { The } \\
\text { column } \\
\text { and the } \\
\text { HPLC } \\
\text { system } \\
\text { remained } \\
\text { in use } \\
\text { between } \\
\text { Month } 1 \\
\text { and } \\
\text { Month } 6 . \\
\text { The } \\
\text { overall \% } \\
\text { RSD is } \\
\text { the } \\
\text { relative } \\
\text { standard } \\
\text { deviation } \\
\text { of all } \\
\text { injections } \\
\text { carried } \\
\text { out for } \\
\text { that } \\
\text { standard } \\
\text { concentration. }\end{array}$ & $\begin{array}{l}\text { All } \\
\text { standard } \\
\text { concentra- } \\
\text { tions were } \\
\text { analyzed } \\
\text { in } \\
\text { triplicates } \\
\text { on } \\
\text { different } \\
\text { months. } \\
\text { The } \\
\text { column } \\
\text { and the } \\
\text { HPLC } \\
\text { system } \\
\text { remained } \\
\text { in use } \\
\text { between } \\
\text { Month } 1 \\
\text { and } \\
\text { Month } 6 . \\
\text { The } \\
\text { overall \% } \\
\text { RSD is } \\
\text { the } \\
\text { relative } \\
\text { standard } \\
\text { deviation } \\
\text { of all } \\
\text { injections } \\
\text { carried } \\
\text { out for } \\
\text { that } \\
\text { standard } \\
\text { concentration. }\end{array}$ & $\begin{array}{l}\text { All } \\
\text { standard } \\
\text { concentra- } \\
\text { tions were } \\
\text { analyzed } \\
\text { in } \\
\text { triplicates } \\
\text { on } \\
\text { different } \\
\text { months. } \\
\text { The } \\
\text { column } \\
\text { and the } \\
\text { HPLC } \\
\text { system } \\
\text { remained } \\
\text { in use } \\
\text { between } \\
\text { Month } 1 \\
\text { and } \\
\text { Month } 6 . \\
\text { The } \\
\text { overall \% } \\
\text { RSD is } \\
\text { the } \\
\text { relative } \\
\text { standard } \\
\text { deviation } \\
\text { of all } \\
\text { injections } \\
\text { carried } \\
\text { out for } \\
\text { that } \\
\text { standard } \\
\text { concentratiol }\end{array}$ \\
\hline
\end{tabular}




\begin{tabular}{|c|c|c|c|c|c|c|c|}
\hline $\begin{array}{l}\text { Table } 6 . \\
\text { Effect of } \\
\text { the guard } \\
\text { column on } \\
\text { the } \\
\text { analysis of } \\
\text { CO6980v0c } 22 \\
\text { gp145. }\end{array}$ & $\begin{array}{l}\text { Table } 6 . \\
\text { Effect of } \\
\text { the guard } \\
\text { column on } \\
\text { the } \\
\text { analysis of } \\
\text { CO6980v0c } 22 \\
\text { gp145. }\end{array}$ & $\begin{array}{l}\text { Table } 6 . \\
\text { Effect of } \\
\text { the guard } \\
\text { column on } \\
\text { the } \\
\text { analysis of } \\
\text { CO6980v0c } 22 \\
\text { gp145. }\end{array}$ & $\begin{array}{l}\text { Table } 6 . \\
\text { Effect of } \\
\text { the guard } \\
\text { column on } \\
\text { the } \\
\text { analysis of } \\
\text { CO6980v0c } 22 \\
\text { gp145. }\end{array}$ & $\begin{array}{l}\text { Table } 6 . \\
\text { Effect of } \\
\text { the guard } \\
\text { column on } \\
\text { the } \\
\text { analysis of } \\
\text { CO6980v0c } 22 \\
\text { gp145. }\end{array}$ & $\begin{array}{l}\text { Table } 6 . \\
\text { Effect of } \\
\text { the guard } \\
\text { column on } \\
\text { the } \\
\text { analysis of } \\
\text { CO6980v0c } 22 \\
\text { gp145. }\end{array}$ & $\begin{array}{l}\text { Table } 6 . \\
\text { Effect of } \\
\text { the guard } \\
\text { column on } \\
\text { the } \\
\text { analysis of } \\
\text { CO6980v0c } 22 \\
\text { gp145. }\end{array}$ & $\begin{array}{l}\text { Table } 6 . \\
\text { Effect of } \\
\text { the guard } \\
\text { column on } \\
\text { the } \\
\text { analysis of } \\
\text { CO6980v0c } 22 \\
\text { gp145. }\end{array}$ \\
\hline $\begin{array}{l}\text { Sample } \\
\text { Concentra- } \\
\text { tion }\end{array}$ & $\begin{array}{l}\text { AUP for } \\
\text { Guard } \\
\text { Column } \\
\text { \#1 Lot\# } \\
\text { USGH002312 }\end{array}$ & Avg. & $\%$ RSD & $\begin{array}{l}\text { AUP for } \\
\text { Guard } \\
\text { Column } \\
\text { \#2 Lot\# } \\
\text { USGH00231 }\end{array}$ & Avg. & $\%$ RSD & $\begin{array}{l}\text { Overall \% } \\
\text { RSD }\end{array}$ \\
\hline $60 \mu \mathrm{g} / \mathrm{ml}$ & $\begin{array}{l}646.399 \\
651.615 \\
652.303\end{array}$ & 650.11 & 0.5 & $\begin{array}{l}657.629 \\
663.513 \\
660.904\end{array}$ & 660.48 & 0.45 & 1.14 \\
\hline $\begin{array}{l}\text { Two } \\
\text { different } \\
\text { guard }\end{array}$ & $\begin{array}{l}\text { Two } \\
\text { different } \\
\text { guard }\end{array}$ & $\begin{array}{l}\text { Two } \\
\text { different } \\
\text { guard }\end{array}$ & $\begin{array}{l}\text { Two } \\
\text { different } \\
\text { guard }\end{array}$ & $\begin{array}{l}\text { Two } \\
\text { different } \\
\text { guard }\end{array}$ & $\begin{array}{l}\text { Two } \\
\text { different } \\
\text { guard }\end{array}$ & $\begin{array}{l}\text { Two } \\
\text { different } \\
\text { guard }\end{array}$ & $\begin{array}{l}\text { Two } \\
\text { different } \\
\text { guard }\end{array}$ \\
\hline $\begin{array}{l}\text { were used } \\
\text { in the }\end{array}$ & $\begin{array}{l}\text { were used } \\
\text { in the }\end{array}$ & $\begin{array}{l}\text { were used } \\
\text { in the }\end{array}$ & $\begin{array}{l}\text { columns } \\
\text { were used } \\
\text { in the }\end{array}$ & $\begin{array}{l}\text { columns } \\
\text { were used } \\
\text { in the }\end{array}$ & $\begin{array}{l}\text { columns } \\
\text { were used } \\
\text { in the }\end{array}$ & $\begin{array}{l}\text { columns } \\
\text { were used } \\
\text { in the }\end{array}$ & $\begin{array}{l}\text { columns } \\
\text { were used } \\
\text { in the }\end{array}$ \\
\hline $\begin{array}{l}\text { injection } \\
\text { of a } \\
\text { standard }\end{array}$ & $\begin{array}{l}\text { injection } \\
\text { of a } \\
\text { standard }\end{array}$ & $\begin{array}{l}\text { injection } \\
\text { of a } \\
\text { standard }\end{array}$ & $\begin{array}{l}\text { injection } \\
\text { of a } \\
\text { standard }\end{array}$ & $\begin{array}{l}\text { injection } \\
\text { of a } \\
\text { standard }\end{array}$ & $\begin{array}{l}\text { injection } \\
\text { of a } \\
\text { standard }\end{array}$ & $\begin{array}{l}\text { injection } \\
\text { of a } \\
\text { standard }\end{array}$ & $\begin{array}{l}\text { injection } \\
\text { of a } \\
\text { standard }\end{array}$ \\
\hline $\begin{array}{l}\text { of known } \\
\text { concentra- } \\
\text { tion. The } \\
\text { overall \% }\end{array}$ & $\begin{array}{l}\text { of known } \\
\text { concentra- } \\
\text { tion. The } \\
\text { overall \% }\end{array}$ & $\begin{array}{l}\text { of known } \\
\text { concentra- } \\
\text { tion. The } \\
\text { overall \% }\end{array}$ & $\begin{array}{l}\text { of known } \\
\text { concentra- } \\
\text { tion. The } \\
\text { overall \% }\end{array}$ & $\begin{array}{l}\text { of known } \\
\text { concentra- } \\
\text { tion. The } \\
\text { overall \% }\end{array}$ & $\begin{array}{l}\text { of known } \\
\text { concentra- } \\
\text { tion. The } \\
\text { overall \% }\end{array}$ & $\begin{array}{l}\text { of known } \\
\text { concentra- } \\
\text { tion. The } \\
\text { overall \% }\end{array}$ & $\begin{array}{l}\text { of known } \\
\text { concentra- } \\
\text { tion. The } \\
\text { overall \% }\end{array}$ \\
\hline $\begin{array}{l}\mathrm{RSD} \text { is } \\
\text { the }\end{array}$ & $\begin{array}{l}\mathrm{RSD} \text { is } \\
\text { the }\end{array}$ & $\begin{array}{l}\mathrm{RSD} \text { is } \\
\text { the }\end{array}$ & $\begin{array}{l}\mathrm{RSD} \text { is } \\
\text { the }\end{array}$ & $\begin{array}{l}\mathrm{RSD} \text { is } \\
\text { the }\end{array}$ & $\begin{array}{l}\mathrm{RSD} \text { is } \\
\text { the }\end{array}$ & $\begin{array}{l}\text { RSD is } \\
\text { the }\end{array}$ & $\begin{array}{l}\mathrm{RSD} \text { is } \\
\text { the }\end{array}$ \\
\hline relative & relative & relative & relative & relative & relative & relative & relative \\
\hline standard & standard & standard & standard & standard & standard & standard & standard \\
\hline $\begin{array}{l}\text { deviation } \\
\text { of all }\end{array}$ & $\begin{array}{l}\text { deviation } \\
\text { of all }\end{array}$ & $\begin{array}{l}\text { deviation } \\
\text { of all }\end{array}$ & $\begin{array}{l}\text { deviation } \\
\text { of all }\end{array}$ & $\begin{array}{l}\text { deviation } \\
\text { of all }\end{array}$ & $\begin{array}{l}\text { deviation } \\
\text { of all }\end{array}$ & $\begin{array}{l}\text { deviation } \\
\text { of all }\end{array}$ & $\begin{array}{l}\text { deviation } \\
\text { of all }\end{array}$ \\
\hline $\begin{array}{l}\text { injections } \\
\text { under }\end{array}$ & $\begin{array}{l}\text { injections } \\
\text { under }\end{array}$ & $\begin{array}{l}\text { injections } \\
\text { under }\end{array}$ & $\begin{array}{l}\text { injections } \\
\text { under }\end{array}$ & $\begin{array}{l}\text { injections } \\
\text { under }\end{array}$ & $\begin{array}{l}\text { injections } \\
\text { under }\end{array}$ & $\begin{array}{l}\text { injections } \\
\text { under }\end{array}$ & $\begin{array}{l}\text { injections } \\
\text { under }\end{array}$ \\
\hline both & both & both & both & both & both & both & both \\
\hline guard & guard & guard & guard & guard & guard & guard & guard \\
\hline columns. & columns. & columns. & columns. & columns. & columns. & columns. & columns. \\
\hline
\end{tabular}

\begin{tabular}{|c|c|c|c|c|}
\hline $\begin{array}{l}\text { Table } 7 \text {. Effect of } \\
\text { column } \\
\text { temperature on } \\
\text { the precision }\end{array}$ & $\begin{array}{l}\text { Table } 7 \text {. Effect of } \\
\text { column } \\
\text { temperature on } \\
\text { the precision }\end{array}$ & $\begin{array}{l}\text { Table } 7 \text {. Effect of } \\
\text { column } \\
\text { temperature on } \\
\text { the precision }\end{array}$ & $\begin{array}{l}\text { Table } 7 \text {. Effect of } \\
\text { column } \\
\text { temperature on } \\
\text { the precision }\end{array}$ & $\begin{array}{l}\text { Table } 7 . \text { Effect of } \\
\text { column } \\
\text { temperature on } \\
\text { the precision }\end{array}$ \\
\hline & $\begin{array}{l}\text { Temperature } 0 \mathrm{C} \\
78\end{array}$ & $\begin{array}{l}\text { Temperature } 0 \mathrm{C} \\
80\end{array}$ & $\begin{array}{l}\text { Temperature } 0 \mathrm{C} \\
82\end{array}$ & Overall \% RSD \\
\hline AUP & $\begin{array}{l}683.690684 .480 \\
684.228\end{array}$ & $\begin{array}{l}689.676692 .576 \\
692.087\end{array}$ & $\begin{array}{l}675.040675 .157 \\
672.157\end{array}$ & 1.11 \\
\hline
\end{tabular}




\begin{tabular}{|c|c|c|c|c|}
\hline $\begin{array}{l}\text { Table } 7 \text {. Effect of } \\
\text { column } \\
\text { temperature on } \\
\text { the precision }\end{array}$ & $\begin{array}{l}\text { Table } 7 . \text { Effect of } \\
\text { column } \\
\text { temperature on } \\
\text { the precision }\end{array}$ & $\begin{array}{l}\text { Table } 7 \text {. Effect of } \\
\text { column } \\
\text { temperature on } \\
\text { the precision }\end{array}$ & $\begin{array}{l}\text { Table } 7 \text {. Effect of } \\
\text { column } \\
\text { temperature on } \\
\text { the precision }\end{array}$ & $\begin{array}{l}\text { Table } 7 \text {. Effect of } \\
\text { column } \\
\text { temperature on } \\
\text { the precision }\end{array}$ \\
\hline Retention Time & 5.3545 .3535 .354 & 5.3315 .3315 .331 & 5.3095 .3115 .309 & 0.36 \\
\hline The overall \% & The overall $\%$ & The overall \% & The overall $\%$ & The overall $\%$ \\
\hline RSD is the & $\mathrm{RSD}$ is the & $\mathrm{RSD}$ is the & $\mathrm{RSD}$ is the & RSD is the \\
\hline relative standard & relative standard & relative standard & relative standard & relative standard \\
\hline deviation of all & deviation of all & deviation of all & deviation of all & deviation of all \\
\hline injections at all & injections at all & injections at all & injections at all & injections at all \\
\hline temperatures. & temperatures. & temperatures. & temperatures. & temperatures. \\
\hline
\end{tabular}

Table 8. Stability of CO6980v0c22 gp145 at 100C.

\begin{tabular}{l} 
Day \\
0 \\
1 \\
2 \\
3 \\
A standard $(60 \mu \mathrm{g} / \mathrm{ml})$ was incubated at $100 \mathrm{C}$ for 3 days and analyzed in triplicates. The Overall Mean AUP $\%$ RSD is the \\
\hline
\end{tabular}

Figures legends

Figure 1. RP-HPLC method specificity . Representative chromatograms obtained from three (3) injections of the HIV-1 CO6980v0c22 gp145 RM (black solid line), SF162 gp140 (black dashed line) and a mobile phase blank (blue solid line) into a Zorbax 300SB-C8 rapid resolution RP-HPLC Column (2.1 x 50 $\mathrm{mm}, 3.5 \mu \mathrm{m})$ mounted on an Agilent BioInert Infinity II 1260 System. The right zoom panel shows the peaks observed for the HIV-1 Env proteins.

Figure 2. Standard curve for CO6980v0c22 HIV-1 gp145 reference material. Samples of reference material were diluted 1:1 in CHO-K1 spent media and injected into the RP-HPLC column. (A) Chromatograms represent the single peak for each of the CO6980v0c22 gp145 RM standards at concentrations of $12.5,25,37.5,50,75$, and $100 \mu \mathrm{g} / \mathrm{ml}$. (B) The area under the curve for each standard injection was plotted as a function of the known concentration. Injections were performed in triplicate and the average of the three injections is reported.

Figure 3. Quantification of CO6980v0c22 gp145 in a bioreactor.A CHO-K1 cell line expressing CO6980v0c22 gp145 was grown in a 40L bioreactor from which samples were removed daily and diluted 1:1 with D-PBS, prior to RP-HPLC analysis. (A) An initial verification of expression was carried out by western blot (WB). The intensity of the WB bands for the culture supernatants, (lanes 2-10), was compared to that of standards of known concentrations, (lanes $12-16)$. The asterisk $(*)$ indicates that the day 10 sample was diluted 1:3. (B) The same samples were analyzed by RP-HPLC and the concentrations plotted to show the daily increase in CO6980v0c22 gp145 production until harvest. 
Figure 1

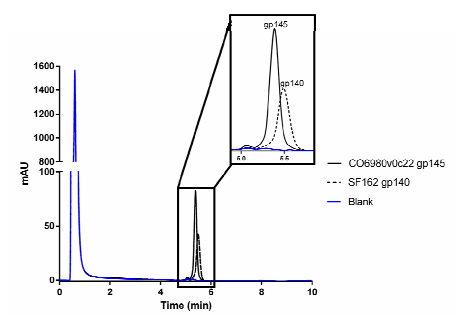

Figure 2

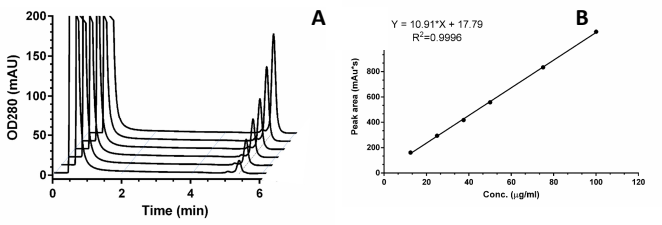


Figure 3

A.

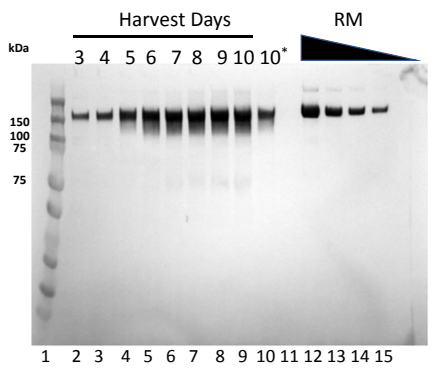

B.

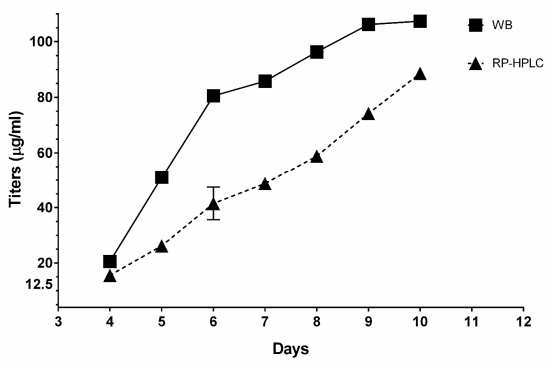

